\title{
Endothelial CD36 Contributes to Postischemic Brain Injury by Promoting Neutrophil Activation via CSF3
}

\author{
Lidia Garcia-Bonilla, Gianfranco Racchumi, Michelle Murphy, Josef Anrather, and Costantino Iadecola \\ Feil Family Brain and Mind Research Institute, Weill Cornell Medical College, New York, New York 10065
}

The scavenger receptor CD36 is a critical factor initiating ischemic brain injury, but the cell type(s) expressing CD36 and responsible for its harmful effects remain unknown. Using bone marrow (BM) chimeras subjected to transient middle cerebral artery occlusion, we found that $\mathrm{CD} 36^{-1-}$ mice transplanted with wild-type $(\mathrm{WT}) \mathrm{BM}\left(\mathrm{WT} \rightarrow \mathrm{CD} 36^{-1-}\right)$ have smaller infarcts $(-67 \%)$, comparable with those of mice lacking $\mathrm{CD} 36$ both in brain and hematogenous cells $\left(\mathrm{CD}^{-1-} \rightarrow \mathrm{CD}^{-1-} 6^{-1-}-72 \%\right)$. Conversely, WT mice receiving $\mathrm{CD}^{-1-}$ $\mathrm{BM}\left(\mathrm{CD} 36^{-1-} \rightarrow \mathrm{WT}\right)$ have infarcts similar to WT $\rightarrow$ WT mice, suggesting that CD36 in the host brain (i.e., in microglia and endothelial cells), and not in hematogenous cells is involved in the damage. As anticipated, postischemic neutrophil infiltration in $\mathrm{CD}^{-1-}$ $\rightarrow \mathrm{CD} 36^{-1-}$ mice was attenuated. Surprisingly, however, in $\mathrm{WT} \rightarrow \mathrm{CD} 36^{-1-}$ mice, in which infarcts were small, neutrophil infiltration was large and similar to that of $\mathrm{CD} 36^{-l-} \rightarrow$ WT mice, in which infarcts were not reduced. Postischemic neutrophil free radical production was attenuated in $\mathrm{WT} \rightarrow \mathrm{CD} 36^{-1-}$ mice compared with $\mathrm{CD}^{-1-} \rightarrow \mathrm{WT}$ mice, whereas expression of the neutrophil activator colonystimulating factor 3 (CSF3) was suppressed in $\mathrm{CD} 6^{-1-}$ cerebral endothelial cells, but not microglia. In $\mathrm{CD}^{-1-}$ cerebral endothelial cultures exposed to extracts from stroke brains, the upregulation of CSF3, but not neutrophil attractant chemokines, was suppressed. Intracerebroventricular administration of CSF3, $24 \mathrm{~h}$ after stroke, reconstituted neutrophil radical production and increased infarct volume in $\mathrm{WT} \rightarrow \mathrm{CD} 36^{-1-}$ mice. The findings identify endothelial cells as a key player in the deleterious effects of $\mathrm{CD} 36$ in stroke, and unveil a novel role of endothelial CD36 in enabling neutrophil neurotoxicity through CSF3.

Key words: flow cytometry; free radicals; postischemic inflammation; scavenger receptor; stroke

\section{Significance Statement}

Ischemic stroke is a leading cause of death and disability worldwide with limited therapeutic options. The inflammatory response initiated by cerebral ischemia-reperfusion contributes to ischemic brain injury and is a potential therapeutic target. Here we report that $\mathrm{CD} 36$, an innate immunity receptor involved in the initiation of postischemic inflammation, is a previously unrecognized regulator of neutrophil cytotoxicity. The effect is mediated by endothelial $\mathrm{CD} 36$ via upregulation of the neutrophil activator CSF3 in cerebral endothelial cells. Therefore, approaches to modulate cerebral endothelial CD36 signaling or to neutralize CSF3 may provide novel therapeutic opportunities to ameliorate postischemic inflammatory injury.

\section{Introduction}

Stroke remains the leading cause of disability worldwide with limited treatment options (Moskowitz et al., 2010). Whereas reestablishing cerebral perfusion with tissue plasminogen activator and/or clot-retrieval devices may improve the outcome of some patients (Campbell et al., 2015a), these interventions have a short therapeutic window or are not widely available, and, as such, can be used only in a minority of stroke patients. Consequently, the

Received Aug. 6, 2015; revised Sept. 22, 2015; accepted Sept. 28, 2015.

Author contributions: L.G.-B., J.A., and C.I. designed research; L.G.-B., G.R., and M.M. performed research; L.G.-B. and G.R. analyzed data; L.G.-B., J.A., and C.I. wrote the paper.

This work was supported by National Institutes of Health Grants NS34179 and NS081179.

The authors declare no competing financial interests.

Correspondence should be addressed to Dr. Costantino ladecola, Feil Family Brain and Mind Research Institute, Weill Cornell Medical College, 407 East 61st Street, New York, NY 10065. E-mail: coi2001@med.cornell.edu.

DOI:10.1523/JNEUROSCI.2980-15.2015

Copyright $\odot 2015$ the authors $\quad 0270-6474 / 15 / 3514783-11 \$ 15.00 / 0$ majority of stroke victims receive only supportive care, highlighting the need for more specific treatments targeting the ischemic cascade (Henninger et al., 2010; Campbell et al., 2015b).

There is increasing evidence that inflammation and immunity play a critical role in the acute phase of ischemic brain injury (Iadecola and Anrather, 2011). Ischemia and reperfusion lead to intravascular molecular events that promote leukocyte adhesion to the cerebral endothelium and their transmigration into the brain and its coverings (Iadecola and Anrather, 2011). At the same time, early brain injury caused by hypoxia generates danger signals or alarmins that activate innate immunity receptors (pattern recognition receptors) in brain and its vasculature, triggering a powerful immune response within the brain (Shichita et al., 2014). These inflammatory responses initiated by hematogenous and brain cells reinforce each other and contribute to the full expression of the tissue damage (An et al., 2014). 
Because of their multiplicity, diverse sources, and redundant mechanisms of action, counteracting individual inflammatory mediators is not a feasible therapeutic strategy, and approaches targeting upstream pathways triggering the inflammatory response are likely to be more fruitful (Iadecola and Anrather, 2011). CD36, a multifunctional Class B scavenger receptor expressed mainly in monocytes/macrophages, microglia, and endothelial cells, has emerged as a critical factor in lipid transport, angiogenesis, as well as sterile inflammation (Silverstein, 2009). In addition to the diverse ligands binding $\mathrm{CD} 36$ (e.g., oxidized low-density lipoprotein, amyloid- $\beta$, thrombospondin), the signaling potential of CD36 is expanded by forming macromolecular complexes with other pattern recognition receptors, such as toll-like receptors (TLR), broadening further its biological impact (Hoebe et al., 2005; Abe et al., 2010; Stewart et al., 2010). Recent data implicate CD36 in the mechanism of ischemiareperfusion. CD36 deletion ameliorates brain damage in models of transient focal cerebral ischemia, an effect linked to suppression of the transcription factor nuclear factor-kappaB, resulting in reduced postischemic inflammation, microglial activation, and free radical production (Cho et al., 2005; Kunz et al., 2008). Therefore, CD36 has emerged as an upstream "damage sensor" initiating and coordinating the expression of multiple inflammatory pathways mediating tissue damage. The cellular mechanisms by which CD36 regulates postischemic inflammation remain to be established. In particular, it remains unclear whether the expression of CD36 in infiltrating hematogenous cells or in resident brain cells is critical for the effects of this receptor in ischemic injury. Furthermore, the factors through which CD36-expressing cells contribute to postischemic inflammation have not been established.

In this study, we used CD36 bone marrow chimeras to provide insight into the cellular and molecular mechanisms by which this scavenger receptor participates in ischemic injury. We found that CD36 in brain cells is responsible for its deleterious effects in ischemic brain injury. Furthermore, using in vivo and in vitro approaches, we found that $\mathrm{CD} 36$ is required for the endothelial expression of CSF3 or granulocyte-colony stimulating factor (G-CSF), and that this cytokine is needed for postischemic neutrophil reactive oxygen species (ROS) production and toxicity. The findings establish endothelial CD36 as a critical link between parenchymal and blood-borne inflammatory responses and highlight a previously unrecognized contribution of endothelial CSF3 to the noxious effects of neutrophils in ischemic brain injury.

\section{Materials and Methods}

Mice. All procedures were approved by the institutional animal care and use committee of Weill Cornell Medical College. Experiments were performed in 8 - to 12 -week-old male CD36 ${ }^{-1-}$ mice on a C57BL/6J genetic background obtained from in-house colonies (Abe et al., 2010). Agematched wild-type (WT) mice (C57BL/6J, The Jackson Laboratory) served as controls. Five-week-old CD $36^{-1-}$ or WT mice were used for cerebral endothelial cell culture. All animal experiments were performed in accordance with the ARRIVE guidelines (Kilkenny et al., 2010).

Middle cerebral artery (MCA) occlusion (MCAo). Transient focal cerebral ischemia was induced using the intraluminal filament model of MCAo, as described previously (Jackman et al., 2011). Under isoflurane anesthesia (maintenance $1.5 \%-2 \%$ ), a heat-blunted nylon suture $(6 / 0)$ was inserted into the right external carotid artery of anesthetized mice and advanced until it obstructed the MCA. This was confirmed by cerebral blood flow measured using transcranial laser Doppler flowmetry (Periflux System 5010, Perimed) in the territory of the right MCA (2 mm posterior, $5 \mathrm{~mm}$ lateral to bregma). The filament was left in place for 35 min and then withdrawn. Only animals that exhibited a reduction in cerebral blood flow of $>85 \%$ during MCAo and in which CBF recovered by $>80 \%$ after $10 \mathrm{~min}$ of reperfusion were included in the study (Jackman et al., 2011). Inadequate ischemia-reperfusion was found to be $<4 \%$ in the study and not different among groups. Rectal temperature was monitored and kept constant $\left(37.0 \pm 0.5^{\circ} \mathrm{C}\right)$ during the surgical procedure and in the recovery period until the animals regained full consciousness. No differences were found in mortality rate $(<1 \%)$ among groups.

Intracerebroventricular injection of CSF3. Mice were anesthetized with isoflurane and placed in a stereotaxic apparatus $24 \mathrm{~h}$ after MCAo. After a small hole was drilled in the left parietal bone (coordinates: $0.5 \mathrm{~mm}$ posterior to bregma and $1.0 \mathrm{~mm}$ lateral from the midline), a glass micropipette was lowered $2.3 \mathrm{~mm}$ below the dural surface and $1 \mu \mathrm{g}$ of CSF3 $(0.1 \mu \mathrm{g} / \mu \mathrm{l}$; Peprotech $)$ or vehicle $(0.1 \%$ BSA in saline $)$ was injected. Mice were allowed to recover and returned to their cages.

Measurement of infarct volume. As described in detail previously (Jackman et al., 2011), infarct volume, corrected for swelling, was quantified by image analysis (MCID, Imaging Research) $72 \mathrm{~h}$ after ischemia in $30-\mu \mathrm{m}$-thick coronal brain sections stained with cresyl violet.

Bone marrow transplantation and chimerism. Whole-body irradiation was performed in 7-week-old male mice $\left(\mathrm{CD} 36^{+/+}\right.$and $\left.\mathrm{CD} 36^{-/-}\right)$with a lethal dose of 9.5 Gy of $\gamma$ radiation using a ${ }^{137} \mathrm{Cs}$ source (Nordion Gammacell 40 Exactor, Theratronics). Eighteen hours later, irradiated mice were transplanted with BM cells $\left(2 \times 10^{6}\right.$, i.v. $)$ isolated from donor $\mathrm{CD}^{+1+}$ (WT) or CD36 ${ }^{-1-}$ (knock-out $[\mathrm{KO}]$ ) mice. Therefore, four groups of chimeric mice were obtained: irradiated WT with WT-BM transplant or irradiated $\mathrm{KO}$ with $\mathrm{KO}-\mathrm{BM}$ transplant, and irradiated chimeric mice, irradiated $\mathrm{KO}$ with WT-BM transplant and irradiated WT with KO-BM. Donor BM cells were flushed out with 2-3 ml of PBS from the femur and tibias, filtered through a $40 \mu \mathrm{m}$ nylon mesh, and counted for viability before injection. Transplanted mice were housed in cages with sulfamethoxazole $(0.12 \%$; w/v) and trimethoprim $(0.024 \%)$ antibiotic added to the drinking water for the first 2 weeks. For histological studies, GFP-transgenic mice (\#006567 The Jackson Laboratory) were used as WT BM donor, and irradiated WT and KO mice were transplanted with $\mathrm{GFP}^{+}$(WT) BM. Reconstitution of BM cells was verified 5 weeks after irradiation by testing the percentage of positive CD36 genomic DNA in isolated blood leukocytes. To this end, $300 \mu \mathrm{l}$ of blood was withdrawn by cardiac puncture from mouse under deep anesthesia, immediately before death. Erythrolysis was performed three times using $5 \mathrm{ml}$ of erythrocyte lysis buffer $\left(0.15 \mathrm{M} \mathrm{NH}_{4} \mathrm{Cl}, 1 \mathrm{~mm} \mathrm{KHCO}_{3}, 0.1 \mathrm{~mm}\right.$ Na-EDTA; 5 min, room temperature). Afterward, DNA was purified from leukocytes using DNeasy Blood and Tissue Kit (QIAGEN \#69504) according to the manufacturer's instructions. Reference primers sequences were as follows: m_ICAM1_prom.3, 5'-GGACTCACCTGCT GGTCTCT-3' and m_ICAM1_prom.4, 5'-GAACGAGGGCTTCGGT ATTT-3'; target primers sequences were as follows: $\mathrm{m}_{-} \mathrm{CD} 36_{-}$ gen.1, 5' -CAGTGCTCTCCCTTGATTCTG-3' and m_CD36_gen.2, 5' CAATAACAGCTCCAGCAATGAG-3', all purchased from Invitrogen. qRT-PCR was conducted with $20 \mathrm{ng}$ of DNA, in duplicate $15 \mu \mathrm{l}$ reactions using the Maxima SYBR Green/ROX qPCR Master Mix $(2 \times)$ (Thermo Scientific). The reactions were incubated at $50^{\circ} \mathrm{C}$ for $2 \mathrm{~min}$ and then at $95^{\circ} \mathrm{C}$ for $10 \mathrm{~min}$. A PCR cycling protocol consisting of $15 \mathrm{~s}$ at $95^{\circ} \mathrm{C}$ and 1 min at $60^{\circ} \mathrm{C}$ for 45 cycles was used for quantification. CD36 relative expression levels were calculated by $2\left(-\Delta \Delta \mathrm{C}_{\mathrm{T}}\right)$ method (Livak and Schmittgen, 2001).

Brain cell isolation. Mice were transcardially perfused under deep anesthesia with $30 \mathrm{ml}$ of heparinized saline to remove blood cells. The ischemic hemisphere was separated from the cerebellum and olfactory bulb and gently triturated in HEPES-Hanks buffered saline solution buffer $\left(138 \mathrm{~mm} \mathrm{NaCl}, 5 \mathrm{~mm} \mathrm{KCl}, 0.4 \mathrm{~mm} \mathrm{Na} \mathrm{HPO}_{4}, 0.4 \mathrm{~mm} \mathrm{KH}_{2} \mathrm{PO}_{4}, 5 \mathrm{~mm}\right.$ D-glucose, 10 mM HEPES) using Gentle MACS dissociator (Miltenyi Biotec) following the manufacturer's instructions. The suspension was digested with $62.5 \mu \mathrm{g} / \mathrm{ml}$ Liberase DH (Roche Diagnostics) and $50 \mathrm{U} / \mathrm{ml}$ DNase I (Worthington Biochemical) at $37^{\circ} \mathrm{C}$ for $45 \mathrm{~min}$ in an orbital shaker at $160 \mathrm{rpm}$. Cells were washed and subjected to discontinuous $70 \% / 25 \%$ Percoll (GE Healthcare) density gradient centrifugation (25 $\left.\min , 800 \times g, 4^{\circ} \mathrm{C}\right)$. Enriched-mononuclear cells were collected from the interphase, washed with HEPES-Hanks buffered saline solution buffer, 
and resuspended in 2\% FBS in PBS FACS buffer for staining and FACS analysis.

Flow cytometry and cell sorting. Rat monoclonal antibodies used for flow cytometry analysis include the following: CD45-APC (clone 30F11), CD11b-PE (clone M1/70), Ly6G-PerCP-Cy5.5 (clone 1A8), and Ly6C-FITC (clone HK1.4), from BioLegend. For blood leukocyte flow cytometry, $100 \mu \mathrm{l}$ of blood was withdrawn by cardiac puncture from mice under deep anesthesia immediately before death. Erythrolysis was performed, as described above; and afterward, blood leukocytes were resuspended in FACS buffer. Isolated brain cells and blood leukocytes were stained at $4^{\circ} \mathrm{C}$ with predetermined optimal concentrations of antibodies for $20 \mathrm{~min}$ and analyzed on an Accuri C6 flow cytometer (BD Biosciences). Dead cells and debris were gated out by forward scatter and side scatter properties. Cell populations were separated based on CD45 and Ly6C expression and further sorted by CD11b and Ly6G expression. Leukocytes were identified as CD $45^{\mathrm{hi}}$ and further gated by CD11b and Ly6G markers. The cell markers used for cell type identification were as follows: neutrophils, CD $45^{\text {hi }} / \mathrm{CD} 11 \mathrm{~b}^{\text {hi }} / \mathrm{Ly} 6 \mathrm{G}^{\text {hi }}$; monocytes/macrophages, CD $45^{\mathrm{hi}} / \mathrm{CD} 11 \mathrm{~b}^{\mathrm{hi}} / \mathrm{Ly} 6 \mathrm{G}^{\mathrm{lo}}$; lymphocytes, CD $45^{\mathrm{hi}} / \mathrm{CD} 11 \mathrm{~b}$ lo Ly6 ${ }^{\text {lo }}$; microglia, CD $45^{\text {int }} / \mathrm{CD} 11 b^{\text {hi }} / \mathrm{Ly}_{6 C^{\mathrm{lo}}}$; and endothelial cells, CD $45^{\text {lo }} /$ Ly6C $^{\text {hi }}$ (Jutila et al., 1988). Blood leukocytes $\left(C D 45^{\text {hi }}\right.$ ) were classified as neutrophils (CD $\left.45^{\text {hi }} / \mathrm{CD} 11 b^{\text {hi }} / \mathrm{Ly}_{6 \mathrm{G}}{ }^{\mathrm{hi}}\right)$, monocytes $\left(\mathrm{CD} 45^{\mathrm{hi}} / \mathrm{CD} 11 \mathrm{~b}^{\text {hi }} / \mathrm{Ly}_{6 \mathrm{G}^{\mathrm{lo}}}\right.$ ), and lymphocytes $\left(\mathrm{CD} 45^{\mathrm{hi}} / \mathrm{CD} 11 \mathrm{~b}^{\text {lo }} /\right.$ Ly $6 \mathrm{G}^{\text {lo }}$ ). Appropriate isotype control antibodies, "fluorescence minus one" staining, and staining of negative populations were used to establish sorting parameters. Absolute cell numbers and frequencies were recorded. Additionally, in other experiments, the cell fractions of neutrophils, monocytes/macrophages, microglia and endothelial cells, identified using the gating strategy detailed above, were sorted on a FACSVantage cytometer (BD Biosciences) for mRNA analysis. In our model of 30 min transient MCAo, the accumulation of leukocytes occurs at $>24 \mathrm{~h}$ after ischemia-reperfusion (Garcia-Bonilla et al., 2014a), as shown by others as well (Gelderblom et al., 2009). However, accumulation at earlier times has been reported with longer ischemic periods (Pérez-de Puig et al., 2015).

In vivo cellular ROS measurement. Intracellular ROS production was detected with dihydroethidium (DHE; Molecular Probes, Invitrogen) staining and flow cytometry analysis. DHE was injected (10 mg/kg, i.v.) $4 \mathrm{~h}$ before animals were killed. DHE is a cell-permanent dye that is oxidized by superoxide (Robinson et al., 2006). The fluorescence signal attributable to DHE oxidation products reflects cumulative ROS production during the period between administration of DHE and killing the animal (Coleman et al., 2013). Isolated brain cells were further costained with CD45-APC, CD11b-APC/Cy7, and Ly6G-PercP/Cy5.5. DHE fluorescence was detected using MACSQuant analyzer (Miltenyi Biotec) with $488 \mathrm{~nm}$ laser and 585/40 nm bandpass filters. DHE-positive cells were identified in infiltrating leukocytes (CD45 ${ }^{\mathrm{hi}}$ ), monocytes/macrophages $\left(\mathrm{CD} 45^{\text {hi }} / \mathrm{CD} 11 \mathrm{~b}^{\text {hi }} / \mathrm{Ly}_{6 \mathrm{G}}{ }^{\mathrm{lo}}\right)$, and neutrophils $\left(\mathrm{CD} 45^{\mathrm{hi}} / \mathrm{CD} 11 \mathrm{~b}^{\mathrm{hi}} / \mathrm{Ly} 6 \mathrm{G}^{\mathrm{hi}}\right)$ using FlowJo software.

Histology of infiltrating GFP ${ }^{+}$leukocytes. WT and CD36 mice transplanted with GFP BM were subjected to MCAo and transcardially perfused with ice-cold PBS followed by 4\% PFA in PBS $72 \mathrm{~h}$ after MCAo. Brains were removed, stored overnight in the same fixative at $4^{\circ} \mathrm{C}$, and then submerged in $30 \%$ sucrose solution for $2 \mathrm{~d}$ and frozen. Then, brains were cut into serial coronal sections (thickness: $16 \mu \mathrm{m}$ ), $600 \mu \mathrm{m}$ apart from each other, through the frontal cortex to the caudal hippocampus using a cryostat. The sections were permeabilized with $0.5 \%$ Triton X-100 (Sigma) in PBS (PBST) for 30 min at room temperature, blocked with $5 \%$ normal donkey serum in $0.1 \%$ in PBST, and incubated with the antibody against the blood vessel marker Collagen IV (1:500, rabbit polyclonal antibody; Abcam) in $1 \%$ normal donkey serum- $-1 \%$ PBST at $4{ }^{\circ} \mathrm{C}$ overnight. After three 10 min washes with $0.1 \%$ PBST, brain slices were incubated with a Cy5-conjugated secondary antibody (1:200; Jackson ImmunoResearch Laboratories). Brain sections were then mounted on slides, and immunostaining was visualized by means of a Leica confocal microscope. The specificity of the immunofluorescence was verified in pilot studies by omission of the primary antibody. $\mathrm{GFP}^{+}$cells associated to vessels or parenchyma were quantified in the cortex and basal ganglia of 4 coronal sections within the ischemic lesion $(1.0,0.4,-0.2$, and -0.8 bregma) using Image J software. $\mathrm{GFP}^{+}$cells within $10 \mu \mathrm{m}$ of the vascular basement membrane (collagen IV) were considered vascular associated and not localized to the brain parenchyma.

Isolation and culture of mouse brain microvascular endothelial cells. For each cell culture, five mouse brains were aseptically collected, pooled and homogenized in isolation medium: 50 mM HEPES, pH 7.4, Medium 199 (Invitrogen) supplemented with $100 \mathrm{U} / \mathrm{ml}$ penicillin and $100 \mu \mathrm{g} / \mathrm{ml}$ streptomycin (Sigma) by Dounce homogenizer (KONTES Dounce Tissue Grinders, Kimble Chase, VWR). The homogenates were suspended in $15 \%$ dextran (average molecular weight 68,800; Fisher Scientific) and centrifuged at $3900 \times g$ for $15 \mathrm{~min}$ at $4^{\circ} \mathrm{C}$ twice. The pellet was washed with isolation medium, centrifuged $\left(1000 \times \mathrm{g}, 10 \mathrm{~min}, 4^{\circ} \mathrm{C}\right)$, and digested with $37.5 \mu \mathrm{g} / \mathrm{ml}$ Liberase DH (Roche Diagnostics) and $110 \mathrm{U} / \mathrm{ml}$ DNaseI in PBS at $37^{\circ} \mathrm{C}$ for $1 \mathrm{~h}$ in an orbital shaker at $75 \mathrm{rpm}$. After incubation, $1 \mathrm{ml}$ of FBS was added to the sample and centrifuged $(1000 \times$ $g, 10 \mathrm{~min}, 4^{\circ} \mathrm{C}$ ). The pellet was resuspended in $4 \mathrm{ml}$ of endothelial cell culture medium (DMEM high glucose; Lonza Walkersville), supplemented with $25 \mu \mathrm{g} / \mathrm{ml}$ endothelial mitogen (Bti, Biomedical Technologies-Alfa Aesar), $100 \mu \mathrm{g} / \mathrm{ml}$ heparin (Sigma), 20\% FBS, 100 $\mathrm{U} / \mathrm{ml}$ penicillin, $100 \mu \mathrm{g} / \mathrm{ml}$ streptomycin, and $4 \mu \mathrm{g} / \mathrm{ml}$ puromycin (Invitrogen). Resuspended cells were seeded on $60 \mathrm{~mm}$ Collagen I (Invitrogen) coated dishes and incubated at $37^{\circ} \mathrm{C}$ with $5 \% \mathrm{CO}_{2}$ in air. After overnight incubation, the medium was changed; and $2 \mathrm{~d}$ later, endothelial cell cultures were placed in cell culture medium without puromycin. Endothelial cells were cultured until the cells became subconfluent and subcultured by TrypLE (Invitrogen) at a 1:3 dilution. Cultures were fed with fresh endothelial cell culture medium every $3 \mathrm{~d}$. Confluent endothelial cells were treated with $10 \%$ brain extract in endothelial cell culture medium $(\mathrm{v} / \mathrm{v})$ for $6 \mathrm{~h}$.

Brain extract preparation. Mouse brains were aseptically collected $24 \mathrm{~h}$ after MCAo or sham surgery. Ischemic and nonischemic hemispheres were dissected and homogenized in 10\% FBS-DMEM at a concentration of $150 \mathrm{mg}$ tissue/ml with a Dounce homogenizer. The suspension was centrifuged $\left(11,000 \times g, 10 \mathrm{~min}, 4^{\circ} \mathrm{C}\right)$, and the supernatant was collected and frozen at $-80^{\circ} \mathrm{C}$ until use.

$q R T-P C R$. The mRNA for chemokines, cytokines, and pro- and antiinflammatory genes was examined by qRT-PCR in sham and ischemic brain hemisphere of chimeric mice $24 \mathrm{~h}$ after MCAo, as previously described (Kunz et al., 2008). The following genes were studied: interleukin (Il)-1 $\beta$, chemokine (C-X-C motif) ligand ( $\mathrm{Cxcl}$ ) 1, 2, and 5, and colony stimulating factor (Csf) 2 and 3. Hypoxanthine-guanine phosphoribosyltransferase (Hprt) was used to normalize gene expression. Data were expressed as mean fold change in the ischemic hemisphere relative to sham brain. Primer sequences, purchased from Invitrogen, were as follows: $I l-1 \beta, \quad 5^{\prime}$-CTCTCCACCTCAATGGACAGA- $3^{\prime}$ and $5^{\prime}$-TTTT GTCGTTGCTTGGTTCTC-3'; Cxcl1, 5'-GCGAAAAGAAGTGCAGA GAGA-3' and 5'-AAACACAGCCTCCCACACAT-3'; Cxcl2, 5'-TG AACAAAGGCAAGGCTAACTG- $3^{\prime}$ and $5^{\prime}$-GAGGCACATCAGGTAC GATCC-3'; $C x c l 5,5^{\prime}$-TGAGAAGGCAATGCTGTCAT- ${ }^{\prime}$ and $5^{\prime}$-CC AGGCTCAGACGTAAGAACA-3'; Csf2, $5^{\prime}$-AGCTCTGAATCCAGCT TCTCA- $3^{\prime}$ and 5' 5 $^{\prime}$ TGGTCCCTTTAAGGCAGAAAT-3'; Csf $3,5^{\prime}$-AG

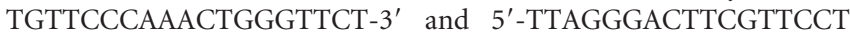
GTGA-3'; and Hprt, 5'-AGTGTTGGATACAGGCCAGAC-3' and $5^{\prime}$ CGTGATTCAAATCCCTGAAGT- ${ }^{\prime}$. Quantitative determination of gene expression from sorted cell fractions was examined as described previously (Garcia-Bonilla et al., 2014a). Briefly, sorted cells were collected in TRIzol LS (Invitrogen), and RNA was extracted as described by Tighe and Held (2010) (and treated with Rnase free DnaseI (Roche) to remove DNA contamination. cDNA was produced from mRNA samples by using the RevertAid First Strand cDNA Synthesis Kit (Thermo Scientific). For isolation of RNA from endothelial cell cultures, RNeasy Plus Mini Kit (QIAGEN) was used. cDNA was produced from mRNA samples by using iScript reverse transcription supermix for RT-qPCR (Bio-Rad). Expression for Cxcl1, Cxcl2, Csf2, and Csf3 genes was performed on a Chromo 4 Detector (Bio-Rad) using a two-step cycling protocol. HPRT was used to normalize gene expression. q-PCR was conducted with cDNA in duplicate $15 \mu \mathrm{l}$ reactions using the Maxima SYBR Green/ROX qPCR Master Mix $(2 \times)$ (Thermo Scientific). The reactions were incubated at $50^{\circ} \mathrm{C}$ for $2 \mathrm{~min}$ and then at $95^{\circ} \mathrm{C}$ for $10 \mathrm{~min}$. A PCR cycling 


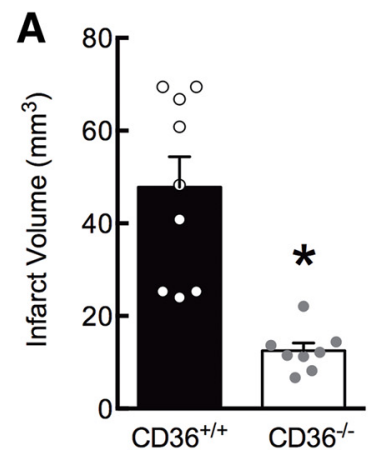

B
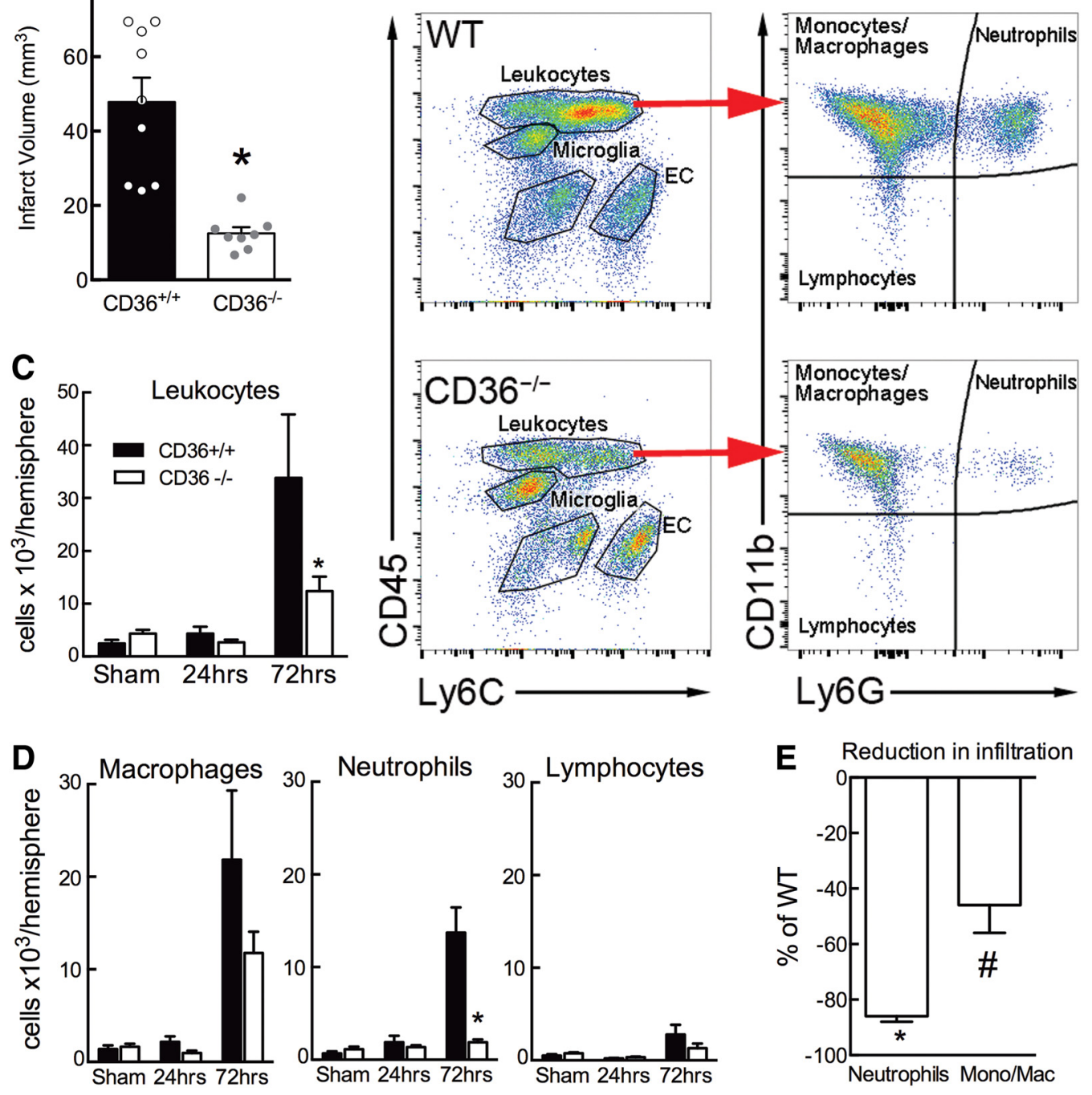

Figure 1. Ischemic injury and leukocyte infiltration are attenuated in $\mathrm{CD}_{3} 6^{-/-}$mice. $A, \mathrm{CD} 6^{-/-}$mice have smaller infarcts than $\mathrm{CD} 36^{+/+}$(WT) $72 \mathrm{~h}$ after MCA0; $n=9$ or 10 mice/group. ${ }^{*} p<0.001$. B , Gating strategy and flow cytometric analysis of infiltrating leukocytes stained for CD45, Ly6C, CD11b, and Ly6G cell surface markers. Six different populations are gated. Infiltrating

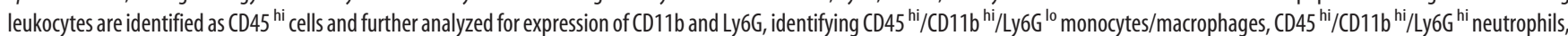

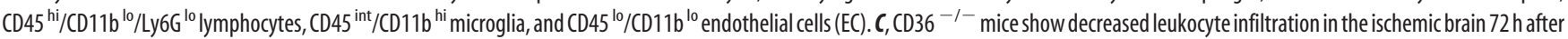
MCAo; $n=6$ mice/group. ${ }^{*} p<0.05$ versus WT. D, A profound decrease of neutrophil infiltration accounts for the reduction in infiltrating leukocytes in the ischemic brain of $C$ 3 $36^{-1-}$ mice compared with WT mice $72 \mathrm{~h}$ after MCA0; $n=6$ mice/group. ${ }^{*} p<0.001$ versus WT. $E$, Neutrophil infiltration is reduced more than monocyte/macrophage infiltration in $C D 36^{-1-}$ mice relative to WT mice; $n=6 /$ group. Values are mean \pm SE. ${ }^{*} p<0.05$ versus WT. ${ }^{\#} p<0.05$ versus neutrophils.

protocol consisting of $15 \mathrm{~s}$ at $95^{\circ} \mathrm{C}$ and $1 \mathrm{~min}$ at $60^{\circ} \mathrm{C}$ for 45 cycles was used for quantification. Cxcl1, Cxcl2, and Csf3 relative expression levels were calculated by the $2\left(-\Delta \Delta \mathrm{C}_{\mathrm{T}}\right)$ method (Livak and Schmittgen, 2001). Csf2 was undetectable in all cell fractions. Data were expressed as mean fold change

Data analysis. Data are expressed as mean \pm SE. Intergroup differences were analyzed using a Student unpaired $t$ test, Kruskal-Wallis test, or one-way ANOVA with Dunnett's post hoc analysis, as appropriate. Differences were considered statistically significant for $p<0.05$. Animals were randomly assigned to treatment and control groups, and analysis was performed in a blinded fashion.

\section{Results}

CD36 is required for the infiltration of BM-derived cells and for the full expression of ischemic brain injury

CD36 deletion reduces the size of the infarct produced by MCAo in mice and dampens postischemic inflammatory gene expression and glial activation (Cho et al., 2005; Kunz et al., 2008).
However, it remains to be established whether CD36 deletion confers protection by preventing the infiltration of BM-derived cells into the postischemic brain. To address this issue, we used flow cytometry to assess the accumulation of BM-derived cells at 24 and $72 \mathrm{~h}$ after ischemia in WT and CD36-null mice. CD36null mice had markedly reduced infarct volumes $72 \mathrm{~h}$ after transient MCAo (Fig. 1A). Neutrophil infiltration was virtually abolished in the brain of CD36-null mice (Fig. $1 B, D, E$ ), whereas monocytes/macrophages were reduced to a lesser extent (Fig. $1 B, D, E)$. Effects on lymphocytes were less pronounced, although the number of these cells was small relative to neutrophils and monocytes/macrophages (Fig. 1D). CD36-null mice have similar numbers of circulating neutrophils (WT: $17 \pm 2 \times 10^{3}$; CD36 $6^{-/-}: 13 \pm 1 \times 10^{3}$ cells $\left./ \mathrm{ml} ; p<0.05\right)$ and monocytes (WT: $19 \pm 3 \times 10^{3} ; \mathrm{CD}^{-1-}: 15 \pm 1 \times 16^{3}$ cells $\left./ \mathrm{ml} ; p>0.05\right)$. Because the number of leukocytes decreased after ischemia both 
A
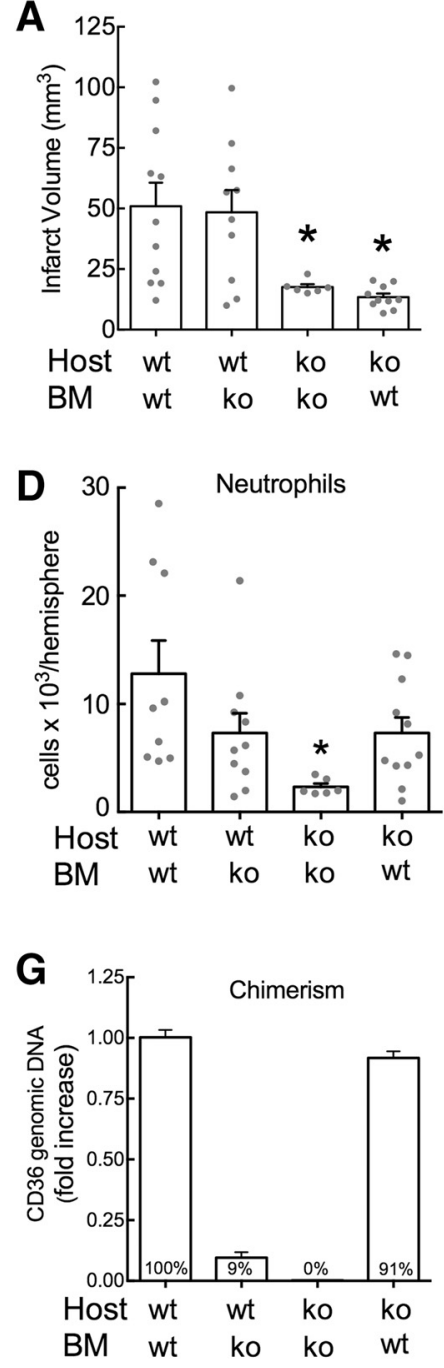

B
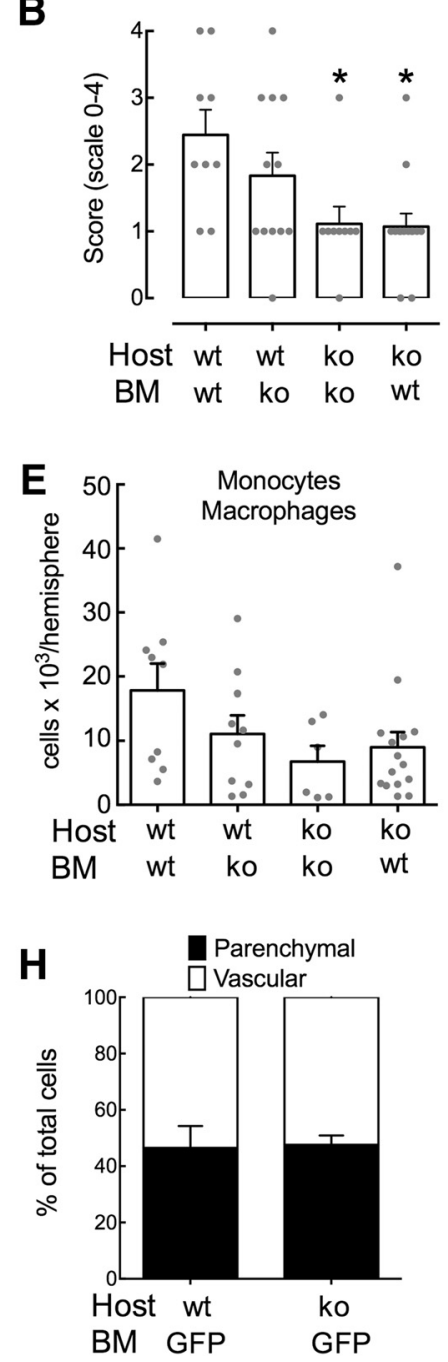

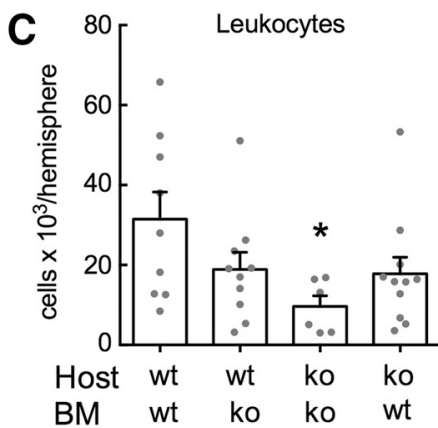

$\mathbf{F}$

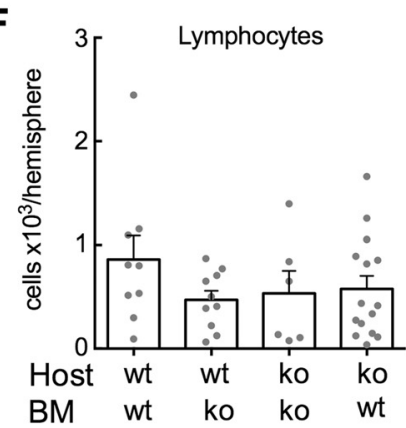

GFP Collagen IV

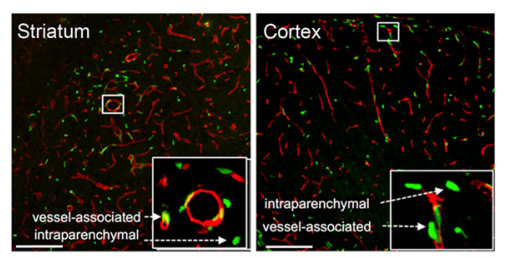

Figure 2. Effect of $C D 36$ expression in brain cells on ischemic damage and leukocyte infiltration. $A, C D 36$-null mice (KO) transplanted with either WT or KO BM had smaller infarcts than WT mice transplanted with either WT or KO BM $72 \mathrm{~h}$ after MCAo $\left(n=9-11\right.$ mice/group). Values are mean \pm SE. ${ }^{*} p<0.05$ versus WT $\rightarrow$ WT. B, CD36-null mice (KO) transplanted either with WT or KOBM had less severe neurological deficit than transplanted WT mice with either WT or KO BM $72 \mathrm{~h}$ after MCAo $\left(n=9-11\right.$ mice/group). Values are mean \pm SE. ${ }^{*} p<0.05$ versus WT $\rightarrow W T$. $C-F$, CD36 expression either in the brain or in hematogenous cells facilitates leukocytes $(\boldsymbol{C}$, neutrophils $(\boldsymbol{D})$, monocytes/macrophages $(\boldsymbol{E})$, and lymphocytes $(\boldsymbol{F})$ to enter the ischemic brain in CD36 chimera mice $72 \mathrm{~h}$ after MCAo $(n=9-11$ mice/group). While leukocytes and neutrophils are decreased in CD36 K0 mice receiving CD36 KO BM compared with WT mice receiving WT marrow, intermediate levels relative to these groups were found in either WT mice receiving CD36 KO BM or CD36 KO mice receiving WT BM. ${ }^{*} p<0.05$ versus WT $\rightarrow$ WT. G, Chimerism in blood leukocytes assayed by genomic qRT-PCR shows a $>90 \%$ engraftment of KO BM cells in the WT host mice or WT BM cells in the KO host mice ( $n=10-15$ mice/group). Values are mean \pm SE. ${ }^{*} p<0.05$ versus WT $\rightarrow$ WT. $H$, Percentage of GFP-infiltrating leukocytes associated with vessels or parenchyma in the brain of WT or CD36 KO host brain $72 \mathrm{~h}$ after MCA0; $n=6 /$ group. Values are mean \pm SE. Right, Infiltrating GFP ${ }^{+}$leukocytes in neocortex or striatum of WT mice $72 \mathrm{~h}$ after MCAo and their association or not with the vascular basement membrane, identified by collagen IV immunocytochemistry. Scale bar, $150 \mu \mathrm{m}$.

in WT (neutrophils: $-29 \%$; monocytes: $-77 \%$; at $72 \mathrm{~h}$ ) and CD36 ${ }^{-/-}$mice (neutrophils: $-13 \%$; monocytes: $-58 \%$; at $72 \mathrm{~h}$ ), it is unlikely that the reduced postischemic infiltration in $\mathrm{CD} 36^{-1-}$ mice versus WT mice is due to differences in the number of these cells in the circulation. Therefore, CD36 deletion is associated with a reduction in BM-derived cells in the ischemic brain, neutrophils in particular.

\section{CD36 in the host is responsible for the injury}

Next, we sought to determine whether CD36 in hematogenous cells or brain resident cells was responsible for the injury. To this end, we performed BM chimera experiments in which CD36 KO $\mathrm{BM}$ was transplanted into WT mice and vice versa. Five weeks later, after full BM engraftment (chimerism >90\%; Fig. 2), mice were subjected to transient MCAo for assessment of ischemic injury and neurological deficit $72 \mathrm{~h}$ later. CD36 KO mice receiv- ing $\mathrm{CD} 36 \mathrm{KO} \mathrm{BM}(\mathrm{KO} \rightarrow \mathrm{KO})$ still exhibited reduced infarcts and improved neurological deficits compared with WT mice receiving WT marrow (WT $\rightarrow$ WT) (Fig. $2 A, B$ ), attesting to the fact that $\mathrm{BM}$ transplant procedures did not alter the neuroprotective effect of CD36 deletion. However, WT mice transplanted with KO BM $(\mathrm{KO} \rightarrow \mathrm{WT})$ had large infarcts comparable with $\mathrm{WT} \rightarrow \mathrm{WT}$ mice, whereas $\mathrm{KO}$ mice receiving WT $\mathrm{BM}(\mathrm{WT} \rightarrow \mathrm{KO})$ had small infarcts and improved neurological outcome like $\mathrm{KO} \rightarrow \mathrm{KO}$ mice (Fig. 2A,B). These findings indicate that CD36 in the host brain, and not in hematogenous cells, is critical for the outcome of cerebral ischemia.

Postischemic neutrophil infiltration in CD36-deficient hosts is not associated with brain injury

We used flow cytometry to determine whether the different outcomes of cerebral ischemia in CD36 BM chimeras could be at- 

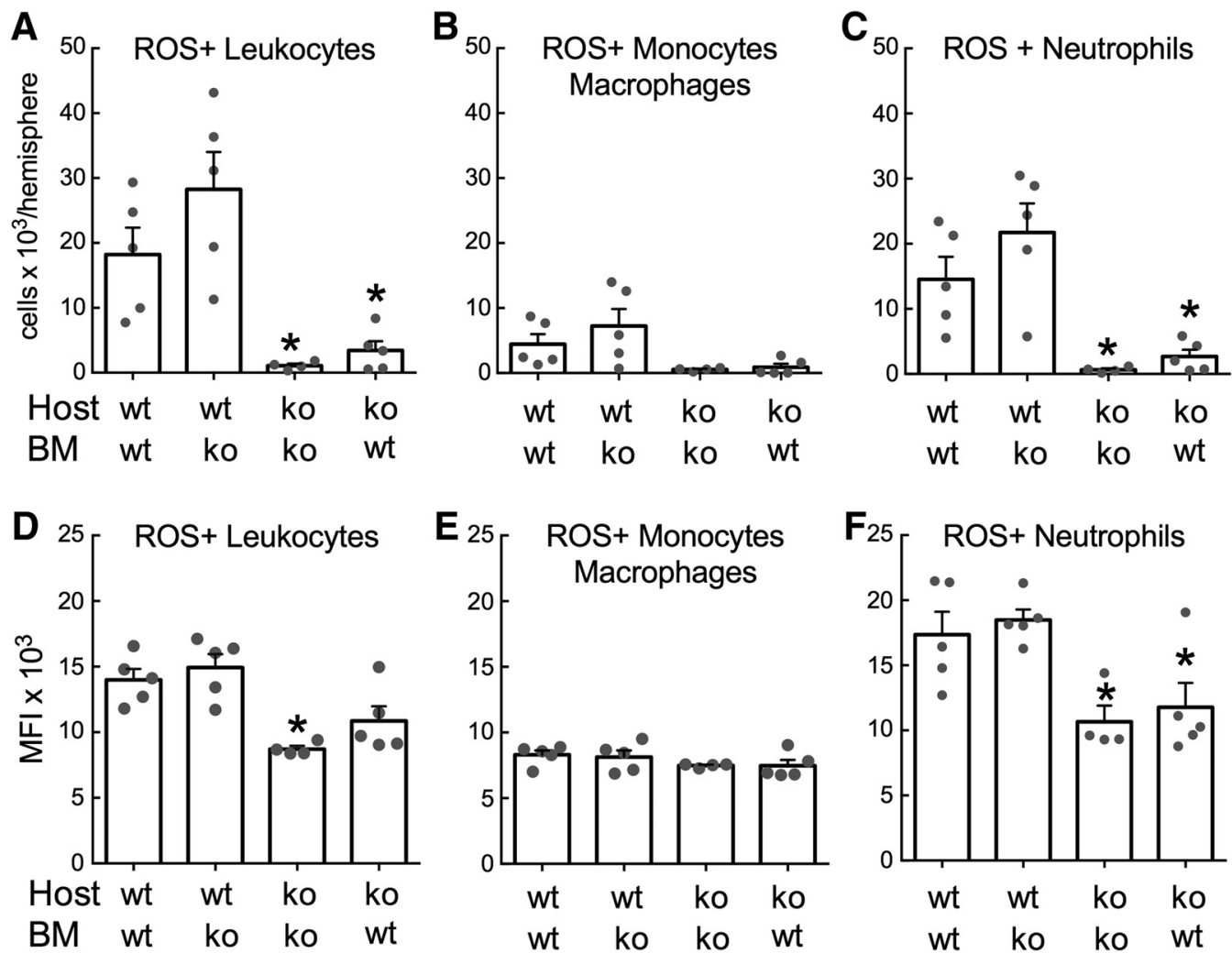

Figure 3. ROS production by infiltrating neutrophils is decreased in CD36-null hosts. $A-C$, Brain leukocytes $(\boldsymbol{A})$, monocytes/macrophages $(\boldsymbol{B})$, and neutrophils $(\boldsymbol{C})$ producing ROS measured by in vivo DHE staining and flow cytometry $72 \mathrm{~h}$ after MCAo in CD36 chimeric mice ( $n=4$ or 5 mice/group). The number of neutrophils producing ROS is reduced in the CD36 KO host accounting for the decrease of the ROS-positive leukocytes. Values are mean \pm SE. ${ }^{*} p<0.05$ versus WT host $\rightarrow$ WT BM. D, E, Median fluorescence intensity (MFI) of DHE signals analyzed by flow cytometry of in brain leukocytes $(\boldsymbol{D})$, monocytes/macrophages $(\boldsymbol{E})$, and neutrophils $(\boldsymbol{F})\left(n=4\right.$ or 5 mice/group). DHE MFI is proportional to the amount of cellular ROS. Values are mean \pm SE. ${ }^{*} p<0.05$ versus WT host $\rightarrow$ WT BM.

tributed to changes in the brain infiltration of BM-derived cells $72 \mathrm{~h}$ after ischemia. As observed in CD36-null mice (Fig. 2C), leukocyte infiltration was attenuated in $\mathrm{KO} \rightarrow \mathrm{KO}$ mice compared with WT $\rightarrow$ WT mice, corresponding to the observed reduction in infarct volume (Fig. 2A). In WT mice receiving KO BM, there was a reduction in monocytes/macrophages and neutrophil infiltration (Fig. $2 D, E$ ), which, however, was not statistically significant or sufficient to reduce injury volume (Fig. 2A). Surprisingly, however, in $\mathrm{KO}$ mice receiving WT BM, in which the infarct was markedly reduced (Fig. $2 A$ ), the neutrophil infiltration was not different from that observed in WT mice receiving $\mathrm{KO} B \mathrm{BM}$ in which the infarct was not reduced (Fig. 2D). This observation attests to the fact that in these mice the accumulation of neutrophils in the postischemic brain is independent of the size of the infarct. No differences in monocytes/macrophages were observed among these groups (Fig. 2E).

To rule out that the neutrophils did not induce brain injury because they were sequestered in or around cerebral microvessels and did not reach the parenchyma, we determined histologically the proportion of vessel-associated and parenchymal leukocytes in WT and $\mathrm{KO}$ mice transplanted with $\mathrm{GFP}^{+} \mathrm{BM}$ (WT for CD36). We found that, although their total number was reduced in the $\mathrm{KO}$ host, there were no differences in the proportion of leukocytes associated with vessels or with the parenchyma (Fig. $2 \mathrm{H}$ ). Therefore, after ischemia, WT neutrophils and other white blood cells enter a CD36-deficient host but are not associated with increased injury.
Postischemic ROS production by WT neutrophils is attenuated in a CD36-deficient host

In cerebral ischemia, as in other inflammatory conditions, ROS production is a major mechanism by which neutrophils damage the brain (Nathan, 2006; Garcia-Bonilla et al., 2014a). Therefore, we sought to determine whether the lack of neutrophil neurotoxicity in a CD36-deficient host after stroke was related to their reduced ability to produce ROS. To this end, we examined ROS production in brain infiltrating leukocytes of CD36 BM chimeras $72 \mathrm{~h}$ after transient MCAo using the oxidative fluorescent dye DHE. In accordance with infarct volumes (Fig. $2 A$ ), the number of leukocyte-producing ROS was significantly reduced in $\mathrm{KO} \rightarrow \mathrm{KO}$ mice compared with $\mathrm{WT} \rightarrow \mathrm{WT}$ mice (Fig. $3 A$ ). Although the number of infiltrating leukocytes was similar in $\mathrm{WT} \rightarrow \mathrm{KO}$ and $\mathrm{KO} \rightarrow \mathrm{WT}$ chimeras (Fig. 2C), ROS-producing leukocytes were reduced in $\mathrm{WT} \rightarrow \mathrm{KO}$ mice to levels comparable with those observed in $\mathrm{KO} \rightarrow \mathrm{KO}$ mice (Fig. $3 A$ ). Analysis of leukocyte subpopulations revealed that neutrophils accounted for the majority of ROS-producing cells (Fig. 3C), whereas only few monocytes/macrophages showed ROS production (Fig. 3B). ROS-positive neutrophils were most abundant in WT mice receiving WT or KO BM and markedly reduced in $\mathrm{KO}$ mice receiving $\mathrm{KO} \mathrm{BM}$, corresponding to the large and small infarct size, respectively. However, ROS-positive neutrophils were also reduced in $\mathrm{KO}$ receiving WT BM, which also have small infarcts (Fig. 3C). Figure 3D-F illustrates the amount of ROS in infiltrating cell in the postischemic brain. Within ROS-producing leuko- 

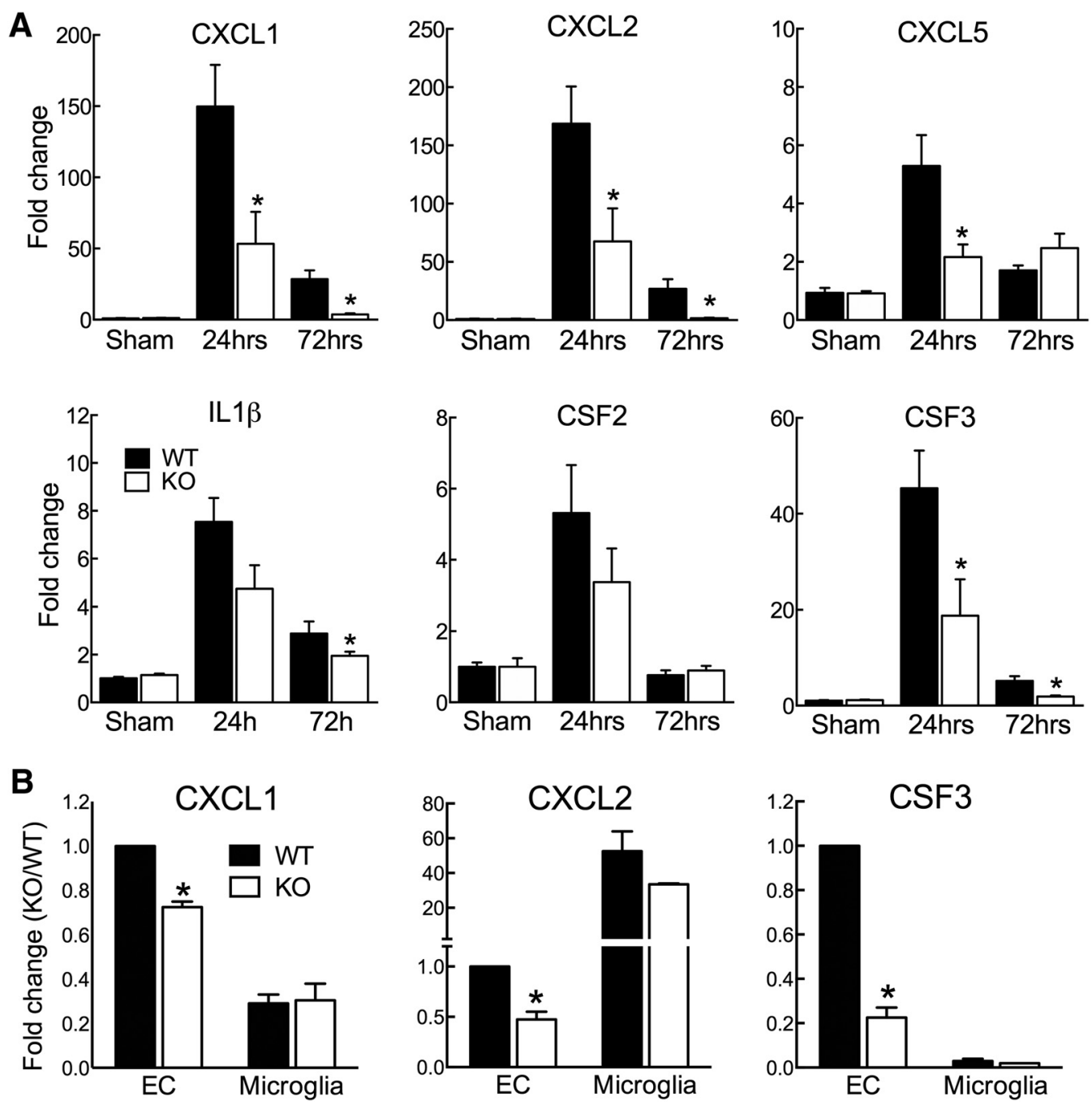

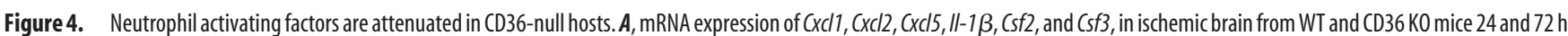
after MCAo or Sham surgery ( $n=5-7$ mice/group). Values are mean \pm SE. ${ }^{*} p<0.05$ versus WT. $B, C x C 11$, CxCl2, and Csf3 mRNA expression assessed in flow cytometric sorted microglia and

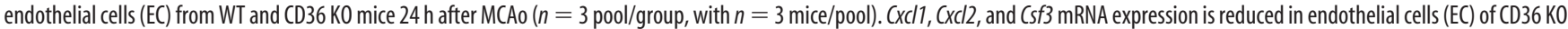
mice. No changes in the microglial expression are observed between WT and CD36 KO mice. ${ }^{*} p<0.05$ versus WT. Values are mean \pm SE.

cytes, the amount of cellular ROS production was also different among groups (Fig. 3D). While cellular ROS levels in infiltrating monocytes/macrophages were similar in the four groups (Fig. $3 E$ ), the cellular ROS production of WT and $\mathrm{KO}$ neutrophils infiltrating a WT host brain was increased compared with neutrophils infiltrating a KO host brain (Fig. $3 F$ ). These observations indicate that postischemic ROS production in WT neutrophils is dampened in a CD36-deficient brain.

Factors involved in neutrophil activation are suppressed in CD36-null mice after stroke

To gain insight into the molecular bases of the reduced neutrophil toxicity in CD36-null mice, we investigated the postischemic expression in brain of factors involved in neutrophil transmigration and activation (Nathan, 2006; Nauseef and Borregaard, 2014). We found that, although Cxcl1, Cxcl2, $C x c l 5, I l-1 \beta, C s f 2$, and $C s f 3$ mRNA were upregulated before neutrophil invasion ( $24 \mathrm{~h}$ after stroke), the expression of Cxcl1, Cxcl2, Cxcl5, and Csf3 was reduced in CD36-null mice (Fig. 4A). Next, we sought to determine the cell type(s) in which these factors are expressed after stroke in a CD36- dependent manner. Because in brain CD36 is present in endothelial cells and microglia (Cho et al., 2005; Park et al., 2011), we determined the expression of neutrophil attracting and activating factors in these cell types. We found that Cxcl1, $C x c l 2$, and particularly Csf3 were reduced in endothelial cells sorted from CD36-null mice $24 \mathrm{~h}$ after stroke (Fig. $4 B$ ). No significant changes in these factors were observed in microglia (Fig. 4B).

\section{CD36 is required for the full expression of endothelial CSF3}

Based on these results, we sought to determine whether CD36 in endothelial cells is needed for the expression of factors involved in neutrophil attraction and activation after stroke. To this end, we exposed cerebral endothelial cells in culture to a brain extract prepared $24 \mathrm{~h}$ after stroke. An extract from the ischemic hemisphere, but not from the contralateral one, induced massive upregulation of Cxcl1, Cxcl2, and Csf3 (Fig. 5A). However, only the Csf 3 induction was markedly suppressed in endothelial cells deficient in CD36 (Fig. 5A) ( $-50 \pm 4 \%$ ), attesting to the requirement of CD36 of its full expression. 

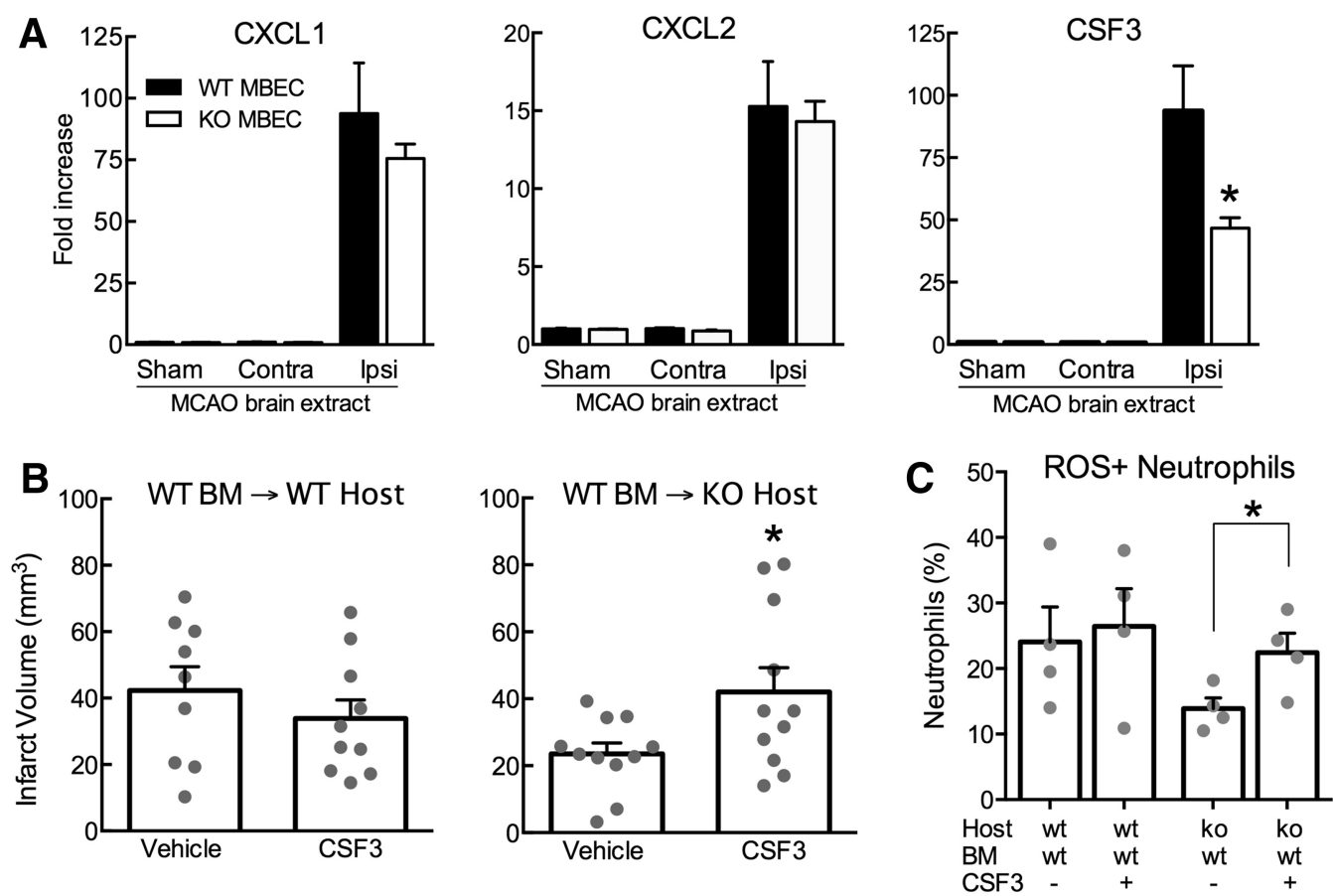

Figure 5. CSF3 is produced by cerebral endothelial cells in a CD36-dependent manner and increases neutrophil ROS and ischemic injury in CD36-null hosts receiving WT BM. A, CXcl1, C $x \mathrm{Cl} 2$, and Csf3 mRNA is upregulated in primary mouse brain endothelial cell (MBEC) cultures exposed for $6 \mathrm{~h}$ to brain extracts from ischemic tissue (Ipsi, ipsilateral hemisphere) but when exposed to brain extract from nonischemic tissue (Sham surgery or Contra, contralateral hemisphere). Reduced production of (sf3 is observed in CD36 KO EC cultures exposed to ischemic brain extract ( $n=6$ /group). ${ }^{*} p<0.05$ versus WT. $B$, Intracerebroventricular administration of CSF3 $(1 \mu \mathrm{g}) 24 \mathrm{~h}$ after MCAo increases ischemic brain injury in CD36 K0 mice receiving WT bone marrow (WT BM $\rightarrow$ KO Host), whereas CSF3 administration does not affect the injury in WT mice receiving WT marrow (WT BM $\rightarrow$ WT Host) $\left(n=9-11\right.$ mice/group). ${ }^{*} p<0.05$ versus vehicle. C, CSF3-mediated reconstitution of ischemic brain injury is accompanied by an increase in the number of neutrophils producing ROS in WT BM $\rightarrow$ KO Host chimeras ( $n=$ 4 mice/group). ${ }^{*} p<0.05$ versus vehicle. Values are mean \pm SE.

CSF3 administrating increases ROS-positive neutrophils and counteracts the protective effect of CD36 deletion

Finally, we tested the effect of restoring cerebral CSF3 levels in chimeric mice in which WT BM was transplanted into a CD36deficient host. In these mice, there was neutrophil infiltration (Fig. 2D), but stroke volume (Fig. 2A) and postischemic ROS production by neutrophils (Fig. 3C) were not increased. Administration of CSF3 into the cerebral ventricles did not increase stroke volume in WT mice receiving WT BM (Fig. 5B). However, in CD36-null mice receiving WT BM, CSF3 administration increased stroke volume and ROS-positive neutrophils (Fig. 5C).

\section{Discussion}

\section{Major findings of the study}

We investigated the cellular mechanism of the effect of CD36 in ischemic brain injury. BM chimera experiments demonstrated that CD36 in the host brain, not in infiltrating hematogenous cells, is required for the full expression of the damage. Thus, the injury was markedly reduced in CD36-null mice transplanted with WT BM. However, the damage was reduced despite significant infiltration of neutrophils, suggesting that these cells cannot fully exert their toxic effect in a CD36-deficient host. Accordingly, the capacity of WT neutrophils to produce postischemic ROS, a major effector of their toxicity, was impaired in a CD36deficient host. Because CD36 in the host brain is present in cerebral endothelial cells and microglia, we examined the expression of factors involved in neutrophil trafficking and activation in these cells, which were sorted from WT and CD36-null brains after stroke. We found that CSF3, a cytokine involved in BM mobilization and neutrophil activation (McLemore et al., 2001; Semerad et al., 2002), is substantially upregulated after stroke
(Fig. 4A), an effect suppressed in cerebral endothelial cells of CD36-null mice. These observations indicated that CD36 is needed for the upregulation of this cytokine, key for neutrophil ROS production. In support of this hypothesis, brain extracts prepared $24 \mathrm{~h}$ after ischemia induced a profound upregulation of Cxcl1 (>90-fold), Cxcl2 (15-fold), and Csf3 (>90-fold) in WT cerebral endothelial cells, but only the $C s f 3$ upregulation was attenuated in CD36-null endothelia. Administration of CSF3 (intracerebroventricular) to CD36-null mice transplanted with WT $\mathrm{BM}$ restored the ability of neutrophils to produce ROS and increased postischemic injury. These findings demonstrate a key role of endothelial CD36 in neutrophil trafficking and activation in the setting of cerebral ischemia, and the involvement of CD36dependent CSF3 expression in postischemic neutrophil toxicity.

\section{CD36 expression in the host is responsible for the damage}

We found that transplantation of WT BM in CD36-null mice did not reconstitute the damage, whereas transplantation of CD36null BM did not confer protection in WT mice, indicating that CD36 expression in the host is responsible for its deleterious effects on the outcome of cerebral ischemia. However, quantitative assessment of the postischemic infiltration of hematogenous cells by flow cytometry revealed that, although transplantation of CD36-null BM reduced the infiltration in a WT host, the damage was not reduced and was comparable with that of WT mice. These findings suggest that lack of CD36 in hematogenous cells reduces the ability of leukocytes to enter the postischemic brain, but this effect is not sufficient to influence brain damage. Indeed, lack of CD36 on infiltrating cells did not reduce the ability of neutrophils to produce ROS. Because blood neutrophils are not known to express CD36 (Ericson et al., 2014), their reduced 
transmigration into the brain may involve interactions with other hematogenous cells expressing the receptors, such as monocytes or platelets (Ghasemzadeh and Hosseini, 2013; Schiwon et al., 2014). Furthermore, the absence of CD36 on neutrophil also rules out that their potential for ROS production is directly impaired by CD36 deletion. In addition, the observation that CD36 ${ }^{-/-}$BM transplanted into WT hosts does not reduce damage argues against the protective effect of CD36 deletion being the result of reduced postischemic intravascular clotting due to a possible role of platelet CD36 (Ghosh et al., 2008).

On the other hand, in a CD36-null host receiving WT BM, brain damage was markedly reduced and not different from that of CD36-null mice. Such damage reduction occurred despite a leukocyte infiltration comparable with that of WT mice receiving CD36-null BM, in which the infarct was as large as in WT mice. In this instance, we found that the ability of infiltrating neutrophils to generate ROS was markedly reduced, indicating that CD36 in the host is needed for neutrophils to produce ROS in the postischemic brain. Collectively, these finding highlight a key role of CD36 in neutrophil infiltration and activation. However, the effect on neutrophil infiltration, which depends on the presence of CD36 in BM-derived cells as well as the host, has no impact on ischemic injury, whereas the effect on neutrophil toxicity, which depends on CD36 in the host, is the major determinant of stroke outcome.

\section{CD36 and neutrophil ROS: role of endothelial CSF3}

We found that CD36 in the host is required for the full production of ROS by neutrophils after stroke. Because ROS are produced by activated neutrophils (Nathan, 2006), we examined the impact of CD36 on factors involved in neutrophil chemoattraction and activation (Mantovani et al., 2011; Nauseef and Borregaard, 2014). We found that, whereas the chemokines CXCL1 and 2 were reduced by $20 \%-40 \%$ in CD36-null cerebral endothelial cells, CSF3, a cytokine critical for neutrophil mobilization and ROS production (Katsura et al., 1993; Sato et al., 1997), was suppressed by $70 \%$. No changes in these factors were observed in CD36-null microglia. On these bases, we hypothesized that reduction of CSF3 in cerebral endothelial cells was related to the lack of neutrophil ROS in CD36-null mice receiving WT BM. To provide supportive evidence for this hypothesis, we exposed primary cerebral endothelial cell cultures to an extract prepared from brains after stroke. We found that this treatment induced substantial upregulation of CXCL1, CXCL2, and CSF3, but only the CSF3 upregulation was CD36-dependent. The observation that exogenous CSF3 restored the ability of neutrophils to produce ROS and reconstituted the damage in CD36-null mice receiving WT BM supports a critical role of this cytokine in neutrophil toxicity.

What is the cellular source of CSF3? Although in brain CD36 is expressed in endothelial cells and microglia (Park et al., 2011; Hickman et al., 2013), we found that the postischemic expression of CSF3 occurs only in endothelial cells. Endothelial cells have been reported to induce neutrophil activation and to potentiate ROS production through hematopoietic growth factors (Takahashi et al., 2001). Furthermore, our in vitro studies indicate that the supernatant of brains subjected to MCAo induced a massive CSF3 response in cerebral endothelial cells. Therefore, the cellular source of CSF3 is likely to be in endothelial cells.

\section{CSF3 and stroke}

CSF3 (G-CSF), best known for its involvement in the mobilization of BM progenitors, especially neutrophil precursors and stem cells, is used extensively to expand BM cells in patients with hematological malignancies and BM transplantation (Beekman and Touw, 2010). In experimental stroke, CSF3 has been shown to be uniformly neuroprotective in the acute and chronic setting through multiple mechanisms, including enhancement of angiogenesis and neurogenesis, as well as suppression of inflammation and apoptosis (England et al., 2009). However, consistent with our results, a recent clinical trial (AXIS 2) has shown no efficacy of acute CSF3 administration after stroke (Ringelstein et al., 2013), highlighting an unanticipated complexity in its role in stroke. CSF3 was previously reported to enhance neutrophil ROS production (Katsura et al., 1993), but in the setting of stroke CSF3 was considered to be protective. Our studies unveil a previously unrecognized "dark side" of CSF3 in ischemic brain injury by demonstrating its involvement in the postischemic ROS production by neutrophils, a CD36-dependent effect. The mechanisms by which endothelial CD36 regulates CSF3 expression remain to be investigated. Oxidized low-density lipoprotein, a well-known CD36 activator, induces CSF3 expression in vascular cells (Kiyan et al., 2014). The effect requires the interaction of CD36 with other receptors, including TLR4 and the urokinase receptor uPAR, which may form a macromolecular complex with CD36 (Kiyan et al., 2014). Similarly, induction of neutrophilactivating genes, including CSF3, was found in endothelial cells exposed to the presumed CD36 ligand serum amyloid A (Lakota et al., 2013), which is upregulated after stroke (Rallidis et al., 2006). It is therefore conceivable that similar mechanisms are responsible for the CD36-mediated CSF3 expression after stroke. However, further studies are required to provide experimental evidence for this hypothesis.

\section{CD36 and alarmins after stroke}

Another questions concerns the ligands activating endothelial CD36 and their source. Brain-generated "danger signals" after stroke could reach endothelial cells either from the abluminal side or from the luminal side after leaking into the circulation (Liesz et al., 2015). CD36 is activated by numerous endogenous ligands, including amyloid- $\beta$, thrombospondin, oxidized lowdensity lipoprotein, surface fragments of apoptotic cells, advanced glycated proteins, cell derived microparticles, and others (Silverstein et al., 2010). The ligands engaging CD36 after stroke remain to be identified and, considering the diverse binding sites of the receptor and its ability to form macromolecular complexes with other pattern recognition receptors, are likely to be multiple. Indeed, we have previously demonstrated that CD36 signaling after stroke requires the TLR2/1 complex (Abe et al., 2010), and requirement for complexes with TLR2/6 and TLR4 have been described in other disease models (Hoebe et al., 2005; Kiyan et al., 2014). Using the endothelial in vitro system exposed to brain extracts after stroke, we are well equipped to identify potential CD36 ligands responsible for CSF3 expression in endothelial cells and ROS production in neutrophils. These experiments, which are beyond the scope of the present study, are underway.

Recent data have implicated CD36 also in Alzheimer's pathology, Parkinson disease, prion diseases, and spinal cord injury (Garcia-Bonilla et al., 2014b), suggesting that the deleterious effects of this receptor are not confined to ischemic brain injury. However, in models of neonatal cerebral ischemia (Woo et al., 2012) and intraparenchymal hemorrhage (Fang et al., 2014; Zhao et al., 2015), CD36 in activated microglia seems to be protective by facilitating the removal of apoptotic cells and the reabsorption of the hematoma, respectively. Therefore, the role of CD36 cannot be assumed to be uniformly beneficial or deleterious but may 
depend on the nature of the injury, its state of evolution, and the age of the host.

In conclusion, we have demonstrated that CD36 has a critical role in the acute damage produced by the inflammatory component of ischemic brain injury. The cellular bases of the tissue damage are related to promoting the infiltration of neutrophil and enhancing their ability to produce ROS. The effect is attributable to CD36 expressed in host cells and not in hematogenous cells infiltrating the postischemic brain. In particular, CD36 in cerebral endothelial cells is essential for the full expression of $\mathrm{CSF} 3$, a potent activator of neutrophil ROS previously considered to be uniformly beneficial in experimental stroke. Collectively, the data identify CD36 in cerebral endothelial cells as a key initiator of innate immune responses after stroke, and highlight a previously unrecognized deleterious role of CSF3 in postischemic neutrophil activation and brain injury. Targeting the endothelial CD36-CSF3 axis may offer a potential new approach to dampen postischemic inflammation and counteract its harmful effects on the ischemic brain.

\section{References}

Abe T, Shimamura M, Jackman K, Kurinami H, Anrather J, Zhou P, Iadecola C (2010) Key role of CD36 in Toll-like receptor 2 signaling in cerebral ischemia. Stroke 41:898-904. CrossRef Medline

An C, Shi Y, Li P, Hu X, Gan Y, Stetler RA, Leak RK, Gao Y, Sun BL, Zheng P, Chen J (2014) Molecular dialogs between the ischemic brain and the peripheral immune system: dualistic roles in injury and repair. Prog Neurobiol 115:6-24. CrossRef Medline

Beekman R, Touw IP (2010) G-CSF and its receptor in myeloid malignancy. Blood 115:5131-5136. CrossRef Medline

Campbell BC, Donnan GA, Lees KR, Hacke W, Khatri P, Hill MD, Goyal M, Mitchell PJ, Saver JL, Diener HC, Davis SM (2015a) Endovascular stent thrombectomy: the new standard of care for large vessel ischaemic stroke. Lancet Neurol 14:846-854. CrossRef Medline

Campbell BC, Meretoja A, Donnan GA, Davis SM (2015b) Twenty-year history of the evolution of stroke thrombolysis with intravenous alteplase to reduce long-term disability. Stroke 46:2341-2346. CrossRef Medline

Cho S, Park EM, Febbraio M, Anrather J, Park L, Racchumi G, Silverstein RL, Iadecola C (2005) The class B scavenger receptor CD36 mediates free radical production and tissue injury in cerebral ischemia. J Neurosci 25: 2504-2512. CrossRef Medline

Coleman CG, Wang G, Faraco G, Marques-Lopes J, Waters EM, Milner TA, Iadecola C, Pickel VM (2013) Membrane trafficking of NADPH oxidase $\mathrm{p} 47$ (phox) in paraventricular hypothalamic neurons parallels local free radical production in angiotensin II slow-pressor hypertension. J Neurosci 33:4308-4316. CrossRef Medline

England TJ, Gibson CL, Bath PM (2009) Granulocyte-colony stimulating factor in experimental stroke and its effects on infarct size and functional outcome: a systematic review. Brain Res Rev 62:71-82. CrossRef Medline

Ericson JA, Duffau P, Yasuda K, Ortiz-Lopez A, Rothamel K, Rifkin IR, Monach PA, ImmGen Consortium (2014) Gene expression during the generation and activation of mouse neutrophils: implication of novel functional and regulatory pathways. PLoS One 9:e108553. CrossRef Medline

Fang H, Chen J, Lin S, Wang P, Wang Y, Xiong X, Yang Q (2014) CD36mediated hematoma absorption following intracerebral hemorrhage: negative regulation by TLR4 signaling. J Immunol 192:5984-5992. CrossRef Medline

Garcia-Bonilla L, Moore JM, Racchumi G, Zhou P, Butler JM, Iadecola C, Anrather J (2014a) Inducible nitric oxide synthase in neutrophils and endothelium contributes to ischemic brain injury in mice. J Immunol 193:2531-2537. CrossRef Medline

Garcia-Bonilla L, Park L, Iadecola C (2014b) Commentary on Myers et al.: growing role of the innate immunity receptor CD36 in central nervous system diseases. Exp Neurol 261:633-637. CrossRef Medline

Gelderblom M, Leypoldt F, Steinbach K, Behrens D, Choe CU, Siler DA, Arumugam TV, Orthey E, Gerloff C, Tolosa E, Magnus T (2009) Temporal and spatial dynamics of cerebral immune cell accumulation in stroke. Stroke 40:1849-1857. CrossRef Medline
Ghasemzadeh M, Hosseini E (2013) Platelet-leukocyte crosstalk: linking proinflammatory responses to procoagulant state. Thromb Res 131:191197. CrossRef Medline

Ghosh A, Li W, Febbraio M, Espinola RG, McCrae KR, Cockrell E, Silverstein RL (2008) Platelet CD36 mediates interactions with endothelial cellderived microparticles and contributes to thrombosis in mice. J Clin Invest 118:1934-1943. CrossRef Medline

Henninger N, Kumar R, Fisher M (2010) Acute ischemic stroke therapy. Expert Rev Cardiovasc Ther 8:1389-1398. CrossRef Medline

Hickman SE, Kingery ND, Ohsumi TK, Borowsky ML, Wang LC, Means TK, Khoury JE (2013) The microglial sensome revealed by direct RNA sequencing. Nat Neurosci 16:1896-1905. CrossRef Medline

Hoebe K, Georgel P, Rutschmann S, Du X, Mudd S, Crozat K, Sovath S, Shamel L, Hartung T, Zähringer U, Beutler B (2005) CD36 is a sensor of diacylglycerides. Nature 433:523-527. CrossRef Medline

Iadecola C, Anrather J (2011) The immunology of stroke: from mechanisms to translation. Nat Med 17:796-808. CrossRef Medline

Jackman K, Kunz A, Iadecola C (2011) Modeling focal cerebral ischemia in vivo. Methods Mol Biol 793:195-209. CrossRef Medline

Jutila MA, Kroese GM, Jutila KL, Stall AM, Fiering S, Herzenberg LA, Berg EL, Butcher EC (1988) Ly-6C is a monocyte/macrophage and endothelial cell differentiation antigen regulated by interferon-gamma. Eur J Immunol 18:1819-1826. CrossRef Medline

Katsura Y, Tsuru S, Noritake M, Kayashima S, Wakiyama H, Shinomiya N, Shinomiya M, Rokutanda M (1993) Granulocyte colony-stimulating factor enhances the extracellular emission of reactive oxygen from neutrophils stimulated with formylmethionylleucylphenylalanine. Cell Immunol 148:10-17. CrossRef Medline

Kilkenny C, Browne WJ, Cuthill IC, Emerson M, Altman DG (2010) Improving bioscience research reporting: the ARRIVE Guidelines for Reporting Animal Research. PLoS Biol 8:e1000412. CrossRef Medline

Kiyan Y, Tkachuk S, Hilfiker-Kleiner D, Haller H, Fuhrman B, Dumler I (2014) oxLDL induces inflammatory responses in vascular smooth muscle cells via urokinase receptor association with CD36 and TLR4. J Mol Cell Cardiol 66:72-82. CrossRef Medline

Kunz A, Abe T, Hochrainer K, Shimamura M, Anrather J, Racchumi G, Zhou P, Iadecola C (2008) Nuclear factor-kappaB activation and postischemic inflammation are suppressed in CD36-null mice after middle cerebral artery occlusion. J Neurosci 28:1649-1658. CrossRef Medline

Lakota K, Mrak-Poljsak K, Bozic B, Tomsic M, Sodin-Semrl S (2013) Serum amyloid A activation of human coronary artery endothelial cells exhibits a neutrophil promoting molecular profile. Microvasc Res 90:55-63. CrossRef Medline

Liesz A, Dalpke A, Mracsko E, Antoine DJ, Roth S, Zhou W, Yang H, Na SY, Akhisaroglu M, Fleming T, Eigenbrod T, Nawroth PP, Tracey KJ, Veltkamp R (2015) DAMP signaling is a key pathway inducing immune modulation after brain injury. J Neurosci 35:583-598. CrossRef Medline

Livak KJ, Schmittgen TD (2001) Analysis of relative gene expression data using real-time quantitative PCR and the 2(-delta delta $\mathrm{C}_{\mathrm{T}}$ ) method. Methods 25:402-408. CrossRef Medline

Mantovani A, Cassatella MA, Costantini C, Jaillon S (2011) Neutrophils in the activation and regulation of innate and adaptive immunity. Nat Rev Immunol 11:519-531. CrossRef Medline

McLemore ML, Grewal S, Liu F, Archambault A, Poursine-Laurent J, Haug J, Link DC (2001) STAT-3 activation is required for normal G-CSFdependent proliferation and granulocytic differentiation. Immunity 14: 193-204. CrossRef Medline

Moskowitz MA, Lo EH, Iadecola C (2010) The science of stroke: mechanisms in search of treatments. Neuron 67:181-198. CrossRef Medline

Nathan C (2006) Neutrophils and immunity: challenges and opportunities. Nat Rev Immunol 6:173-182. CrossRef Medline

Nauseef WM, Borregaard N (2014) Neutrophils at work. Nat Immunol 15: 602-611. CrossRef Medline

Park L, Wang G, Zhou P, Zhou J, Pitstick R, Previti ML, Younkin L, Younkin SG, Van Nostrand WE, Cho S, Anrather J, Carlson GA, Iadecola C (2011) Scavenger receptor CD36 is essential for the cerebrovascular oxidative stress and neurovascular dysfunction induced by amyloid-beta. Proc Natl Acad Sci U S A 108:5063-5068. CrossRef Medline

Pérez-de Puig I, Miró-Mur F, Ferrer-Ferrer M, Gelpi E, Pedragosa J, Justicia C, Urra X, Chamorro A, Planas AM (2015) Neutrophil recruitment to the brain in mouse and human ischemic stroke. Acta Neuropathol 129: 239-257. CrossRef Medline 
Rallidis LS, Vikelis M, Panagiotakos DB, Rizos I, Zolindaki MG, Kaliva K, Kremastinos DT (2006) Inflammatory markers and in-hospital mortality in acute ischaemic stroke. Atherosclerosis 189:193-197. CrossRef Medline

Ringelstein EB, Thijs V, Norrving B, Chamorro A, Aichner F, Grond M, Saver J, Laage R, Schneider A, Rathgeb F, Vogt G, Charissé G, Fiebach JB, Schwab S, Schäbitz WR, Kollmar R, Fisher M, Brozman M, Skoloudik D, Gruber F, et al. (2013) Granulocyte colony-stimulating factor in patients with acute ischemic stroke: results of the AX200 for Ischemic Stroke trial. Stroke 44:2681-2687. CrossRef Medline

Robinson KM, Janes MS, Pehar M, Monette JS, Ross MF, Hagen TM, Murphy MP, Beckman JS (2006) Selective fluorescent imaging of superoxide in vivo using ethidium-based probes. Proc Natl Acad Sci U S A 103:1503815043. CrossRef Medline

Sato N, Kashima K, Tanaka Y, Shimizu H, Mori M (1997) Effect of granulocyte-colony stimulating factor on generation of oxygen-derived free radicals and myeloperoxidase activity in neutrophils from poorly controlled NIDDM patients. Diabetes 46:133-137. CrossRef Medline

Schiwon M, Weisheit C, Franken L, Gutweiler S, Dixit A, Meyer-Schwesinger C, Pohl JM, Maurice NJ, Thiebes S, Lorenz K, Quast T, Fuhrmann M, Baumgarten G, Lohse MJ, Opdenakker G, Bernhagen J, Bucala R, Panzer U, Kolanus W, Gröne HJ, et al. (2014) Crosstalk between sentinel and helper macrophages permits neutrophil migration into infected uroepithelium. Cell 156:456-468. CrossRef Medline

Semerad CL, Liu F, Gregory AD, Stumpf K, Link DC (2002) G-CSF is an essential regulator of neutrophil trafficking from the bone marrow to the blood. Immunity 17:413-423. CrossRef Medline
Shichita T, Ito M, Yoshimura A (2014) Post-ischemic inflammation regulates neural damage and protection. Front Cell Neurosci 8:319. CrossRef Medline

Silverstein RL (2009) Inflammation, atherosclerosis, and arterial thrombosis: role of the scavenger receptor CD36. Cleve Clin J Med 76 [Suppl 2]:S27-S30. CrossRef Medline

Silverstein RL, Li W, Park YM, Rahaman SO (2010) Mechanisms of cell signaling by the scavenger receptor CD36: implications in atherosclerosis and thrombosis. Trans Am Clin Climatol Assoc 121:206-220. Medline

Stewart CR, Stuart LM, Wilkinson K, van Gils JM, Deng J, Halle A, Rayner KJ, Boyer L, Zhong R, Frazier WA, Lacy-Hulbert A, El Khoury J, Golenbock DT, Moore KJ (2010) CD36 ligands promote sterile inflammation through assembly of a Toll-like receptor 4 and 6 heterodimer. Nat Immunol 11:155-161. CrossRef Medline

Takahashi T, Hato F, Yamane T, Fukumasu H, Suzuki K, Ogita S, Nishizawa Y, Kitagawa S (2001) Activation of human neutrophil by cytokineactivated endothelial cells. Circ Res 88:422-429. CrossRef Medline

Tighe S, Held MA (2010) Isolation of total RNA from transgenic mouse melanoma subsets using fluorescence-activated cell sorting. Methods Mol Biol 632:27-44. CrossRef Medline

Woo MS, Wang X, Faustino JV, Derugin N, Wendland MF, Zhou P, Iadecola C, Vexler ZS (2012) Genetic deletion of CD36 enhances injury after acute neonatal stroke. Ann Neurol 72:961-970. CrossRef Medline

Zhao X, Sun G, Ting SM, Song S, Zhang J, Edwards NJ, Aronowski J (2015) Cleaning up after ICH: the role of Nrf2 in modulating microglia function and hematoma clearance. J Neurochem 133:144-152. CrossRef Medline 